\title{
Taekwondo Sports Equipment Business Management in Semarang City
}

\section{Prima Ganda Saputra ${ }^{1 *}$, Tri Nurharsono ${ }^{2}$, Heny Setyawati ${ }^{3}$, Endro Puji Purwono4}

${ }^{1 * 234}$ Department of Physical Education Heath and Recreation, Faculty of Sport Science, Universitas Negeri Semarang, Indonesia

\author{
Article History: \\ Received: 2 April 2021 \\ Accepted: 23 April 2021 \\ Published: 26 April 2021
}

Keywords:

Management; Industry; Sport

\begin{abstract}
The purpose of this study is to figure out the existence of the taekwondo supply business in Semarang. This study approach uses descriptive method. Techniques of collecting data using purposive sampling. Sources of data in the form of primary data and secondary data. The primary data obtained by interview and observation while secondary data obtained by documentation. Source triangulation and technique triangulation are used to examine the validity of the data. Data analysis obtained by reduction, display data, and conclusion. Based on the research in Semarang, there is a taekwondo supply business that has distributed their goods to several regions in Indonesia. In the operational level, these two companies still use manual methods in the production process and the human resources used are taken from the local community. Basically, these two companies have carried out the management process, while the financial aspects of these two companies differ in capital and objectives. For the information systems, ZAO makes better use of them. The company has a fairly good management system because it has fulfilled its four management functions, namely planning, organizing, implementing and controlling. Suggestion the taekwondo supply company in Semarang should develop their marketing management in order to maintain its stability in the field of the taekwondo supply business.
\end{abstract}

\section{How To Cite:}

Saputra, P. G, Nurharsono, T, Setyawati, H, \& Purnomo, E. P. (2021). Taekwondo Sports Equipment Business Management in Semarang City. Indonesian Journal of Sport Management, 1(1), 31-40. https://doi.org/10.31949/ijsm.v1i1.990

Corresponding author: Prima Ganda Saputra, Department of Physical Education Heath and Recreation, Faculty of Sport Science, Universitas Negeri Semarang, Central Java, Indonesia

Email: primaganda@gmail.com 


\section{INTRODUCTION}

Law of the Republic of Indonesia Number 20 of 2008 concerning micro, small and medium enterprises, that micro, small and medium enterprises are business activities capable of expanding employment, providing broad economic services to the community, equitable distribution. community economy, improve the community economy. However, even so, micro and medium enterprises still face various problems ranging from sales, capital and human resources. These constraints are felt by the micro sports industry.

According to Priyono (2012), strengthening public policies on poverty alleviation efforts through the development of the micro sports industry. The sports industry is one of the most important aspects in the economic development of a country. In countries such as America, England, Germany, France, Italy, Korea, and China, the sports industry is growing rapidly, even becoming a leading industry as a supplier of foreign exchange. In building national character, sport has become an industrial identity that has significant added value. In Indonesia, the development of the sports industry requires the participation of the community in realizing sports that excel with the support of the domestic sports industry. The state ministry of youth and sports through the deputy of youth entrepreneurship and sports industry in Indonesia has launched an idea to develop the sports industry as a creative, empowered industry high competitiveness.

According to economics, business is an organization that sells goods or services, is busy doing activities and jobs that bring consumers or other businesses. Business comes from bussiness which means busy or busy in the context of an individual, community or society. In the sense of profit. Etymologically, business means a situation in which a person or group of people is busy doing work that generates profits. The word "business" has three uses, depending on the scope - the singular use of the word business can refer to a business entity, namely a juridical (legal), technical, and economic entity aimed at profit or profit. Broader usage can refer to a specific market sector. Yang (Zhan, 2016) state that, the sports industry is defined as the production unit of sports-related products and services, including sports organization and administration, sports venue management, fitness and entertainment, sports intermediation, sports training, sports lottery, production of sports goods and equipment, sales of goods. and sports equipment, and construction of sports venues.

The understanding of the sports industry in Chapter I paragraph (18) of the general provisions of Law No. 3 of 2005 concerning the national sports system is a business activity in the field of sports in the form of products and / services. Sports management professionals generally believe that sport as participation is more important to American society than sport as entertainment. Indeed, the plurality of sports management professionals in this study are reported to be working in the context of community recreation. At the same time, sport as entertainment is a more attractive career path for most sport management students and alumni. The variety of sports management careers reported by respondents indicates that graduates explore and accept positions in many fields to pursue desired careers in the sports industry. They understand the growing role of sport in American society and they want to be a part of it (Schwab et al., 2015). 
Sport is a global industry that influences many other sectors of the economy through its own traditions and relationships with society. There are tacit and unwritten rules about the sport that set it apart from other segments of the industry (Ratten, 2016). As a discipline, sports management is still in its infancy but has grown in scholarship and significance in relation to the integral role of sport in society (Peachey, Borland, Lobpries, \& Cohen, 2015; Ratten, 2016).

Engagement with sports equipment has received little direct research attention, although it has been studied regularly in the context of defining recreational specialization (Bryan 1977; Bryan 1979; Donnelly et al. 1986; Bloch, et. al., 1989). According to this stream of research, commitment to sport is exemplified by specific behaviors and the use of certain equipment which represent a larger than average financial investment. Highly specialized sports participants seek maximum recreational satisfaction and rely on sports equipment as a means of achieving that goal. So, there appears to be a two-stage process at work. Commitment to recreation generates high involvement or interest in related equipment which in turn is associated with outcomes such as high equipment expenditure rates (Bloch, et. al., 1989).

The numbers of marketing definitions presented in literature have led to ambiguity about what marketing is for marketing managers, senior management and other functional managers. McDonald (Contreras and Ramos, 2015) states that although there are many "admirable and correct" definitions, these definitions provide little guidance on what to include and exclude in the marketing practice. Definitions of the American Marketing Association show that marketing is much more than promotion and personal selling (Kerin, Hartley, \& Rudelius, 2013; Contreras and Ramos, 2015). They have academic and professional relevance and are developed using the consensus of academic and professional marketers.

Marketing is a social and managerial process in which individuals and groups get what they need and want by creating and exchanging products and services and values between one person and another. The role of marketing today is not only to deliver products or services into the hands of consumers, but also how these products or services can provide satisfaction to customers on an ongoing basis, so that company profits can be obtained by the occurrence of repeated purchase (Putri, 2014). There are several kinds of understanding strategies from experts. According to Marrus (Umar, 2001; Wibowo, et al., 2015) strategy is defined as a process of determining the plans of top leaders that focus on the long-term goals of the organization, along with the preparation of a method or effort to achieve these goals. Prahalad (Umar, 2001; Wibowo, et al., 2015) states that strategy is specifically defined as actions that are incremental (always increasing) and continuous, and carried out based on the point of view of what customers expect in the future.

The taekwondo equipment industry business carried out by the ZAO and ADSUS brands is in the city of Semarang. From preliminary observations, information is obtained that this industrial business is always growing from year to year, although in terms of marketing the products produced are only consumed by taekwondo sports players and are not generally consumed by the wider community on an ongoing basis.

Fulfilling the need for various types of taekwondo sports equipment has made taekwondo equipment manufacturers in Semarang start producing taekwondo 
equipment that dare to compete with foreign products. It is from this business that taekwondo equipment manufacturers have begun to benefit from the production of taekwondo sports goods and services which are of course in accordance with the standards of facilities and infrastructure used in taekwondo sports. Taekwondo sports facilities and infrastructure are very diverse, the diversity of taekwondo equipment is caused by developments in technology and knowledge. From year to year there have been several changes to the model of the equipment.

\section{METHOD}

The method used in this research is descriptive qualitative survey research type. Surveys are used to determine and measure a broad range of information, such as knowledge, attitudes, values, opinions, actions, intentions, behaviours and beliefs (Wagstaff, 2006; Polit and Beck, 2010; Robert, 2012).

They are a valuable research method to examine comparisons and variations between large groups of people, providing the researcher with a broad overview of a certain situation or phenomena and potentially to provide a platform for further studies (Hallberg, 2008 Robert, 2012). Survey research is, however, reliant on the willingness of the respondents to take part; it is therefore important that time and consideration are spent on its design to encourage participation.

A survey is essentially quantitative in nature (Polit and Beck, 2010; Robert, 2012); although 'qualitative aspects' may be present in the form of open questions, data analysis is always determined by statistical analysis. Though surveys belong to the quantitative paradigm, they are non-experimental in design (Parahoo, 2006; Robert, 2012); variables are not manipulated, but information is gathered about the variables to determine or measure their relationships to one another, whereas experimental research involves the manipulation of at least one variable (Watson and Keady, 2008; Robert, 2012).

The goal of sampling strategies in survey research is to obtain a sufficient sample that is representative of the population of interest. It is often not feasible to collect data from an entire population of interest (e.g., all individuals with lung cancer); therefore, a subset of the population or sample is used to estimate the population responses (e.g., individuals with lung cancer currently receiving treatment) (Ponto, 2015). Locations in the ZAO and ADSUS brand places with respondents 14 ZAO employees and 8 ADSUS employees. The data collection techniques used in this study were observation, interviews, and documentation. The data analysis method used in this research is descriptive qualitative analysis. Qualitative descriptive analysis is describing completely and accurately the data obtained from various sources to achieve research objectives. In the qualitative data analysis activities, they are grouped into three stages, namely data reduction, data presentation, conclusion and drawing.

\section{RESULT AND DISCUSSION}

\section{Marketing Aspects}

The marketing of the two taekwondo equipment companies in Semarang City has not fulfilled the Marketing Mix which consists of: 1) Develop a product, 2) 
Determine the price, 3) Spread it to various places, 4) Promote it to be purchased by consumers.

Both brands have produced equipment that meets the standards and criteria for taekwondo sports equipment. The company's consistency in making taekwondo equipment is also good. The drawbacks of these two companies are seen from the work process which still depends on orders, and sometimes product processing and product delivery exceed the deadline for processing orders. This is a negative value that will have an impact on decreasing the level of customer satisfaction for the two companies.

Table 1. Product concepts, sales concepts and marketing concepts

\begin{tabular}{|c|c|c|}
\hline Aspects & ZAO & ADSUS \\
\hline Product Aspects & $\begin{array}{l}\text { - Using the same type of } \\
\text { material for clothes. The } \\
\text { striated channel is a little stiff } \\
\text { The target / pad uses the } \\
\text { same semi-skin material } \\
\text { with } 3-4 \mathrm{~cm} \text {. } \\
\text { - Semi-leather body armor } \\
\text { with a thickness of } 7-8 \mathrm{~cm}\end{array}$ & $\begin{array}{l}\text { - Use the same type of material } \\
\text { for the channel with a softer } \\
\text { material } \\
\text { - The target / pad uses the } \\
\text { same semi-skin material with } \\
4-5 \mathrm{~cm} \\
\text { - Semi-leather body armor } \\
\text { with a thickness of } 7-8 \mathrm{~cm}\end{array}$ \\
\hline Sales Aspect & $\begin{array}{l}\text { - Using the ordering system } \\
\text { - In } 1 \text { month, approximately } \\
\text { IDR 20,000,000 to IDR } \\
30,000,000\end{array}$ & $\begin{array}{l}\text { - Using an ordering system } \\
\text { - Within } 1 \text { month, Rp. } \\
25,000,000, \\
40,000,000,\end{array}$ \\
\hline Marketing Aspects & $\begin{array}{l}\text { Using social media and business } \\
\text { partners }\end{array}$ & $\begin{array}{l}\text { Using business relations } \\
\text { partners }\end{array}$ \\
\hline
\end{tabular}

In the manufacture of ZAO and ADSUS, they have not set product standards to consumers. Because in this case ZAO and ADSUS themselves are still classified as a cottage industry. The standardization of taekwondo equipment and clothes, both ADSUS and ZAO, was different because the two brand owners were in the manufacturing process based on observations. So that for quality materials that are affordable but do not close reduce the convenience factor and consumer desires.

The marketing activities of a company have several goals to be achieved, both short-term and long-term goals. In the short term, it is usually to win the hearts of consumers, especially for newly launched products. Meanwhile, in the long term, this is done to maintain existing products in order to continue to exist. In general, understanding the concept of marketing, it is necessary to introduce an understanding of the concept of a marketing strategy. To deal with in getting customers, a company must realize that it is not young without a real action in the form of hard work by using the right strategy to increase the number of customers, strategy is an important key to the success of a company in reaching customers. Consumers are currently facing a variety of choices of products, brands, prices, and suppliers. To determine the intention to take, consumers will consider which offers will provide the highest benefits and value to build and run a business to be successful and reliable, not just fixated on a few either the product or service you are offering. An important factor in the is in that also affects consumer satisfaction with products or services from the business is the existence of good service (Rusdi, 2019). 
In making ZAO and ADSUS still have not set product standards to consumers. Because in this case, ZAO and ADSUS are still classified as home-based industry. The standardization of taekwondo equipment and clothes, both ADSUS and ZAO, was different because the two brand owners were in the manufacturing process based on observations.

\section{Operational Aspects}

The production capacity of a company is different from other companies. Even though they come from one area, these companies have different production capacities. Production capacity is also largely determined by the state of the production equipment and machines used. In its production, ZAO is preferred because the number of production tools and the number of employees are more weighted by ADSUS. ZAO with 4 sewing tools while ADSUS 3 sewing tools for making clothes or dobok. These two companies are companies that still use manual methods in their production processes.

Production results are largely determined by the expertise of employees in the manufacture of products and in operating the tools. ZAO and ADSUS are in accordance with the theory which states that for the manufacturing industry business, for example, it is necessary to discuss the production capacity, the type of technology used, the use of equipment and machines, the location of the factory and the most profitable factory layout.

The company has a location for reasons of safety and comfort in the production process, as well as minimizing the bad impact on the surrounding community. The placement of ZAO production is preferred because it is in one scope in the sense of one place, while the ADSUS is divided into two by making clothes and equipment.

Table 2. Production Concept

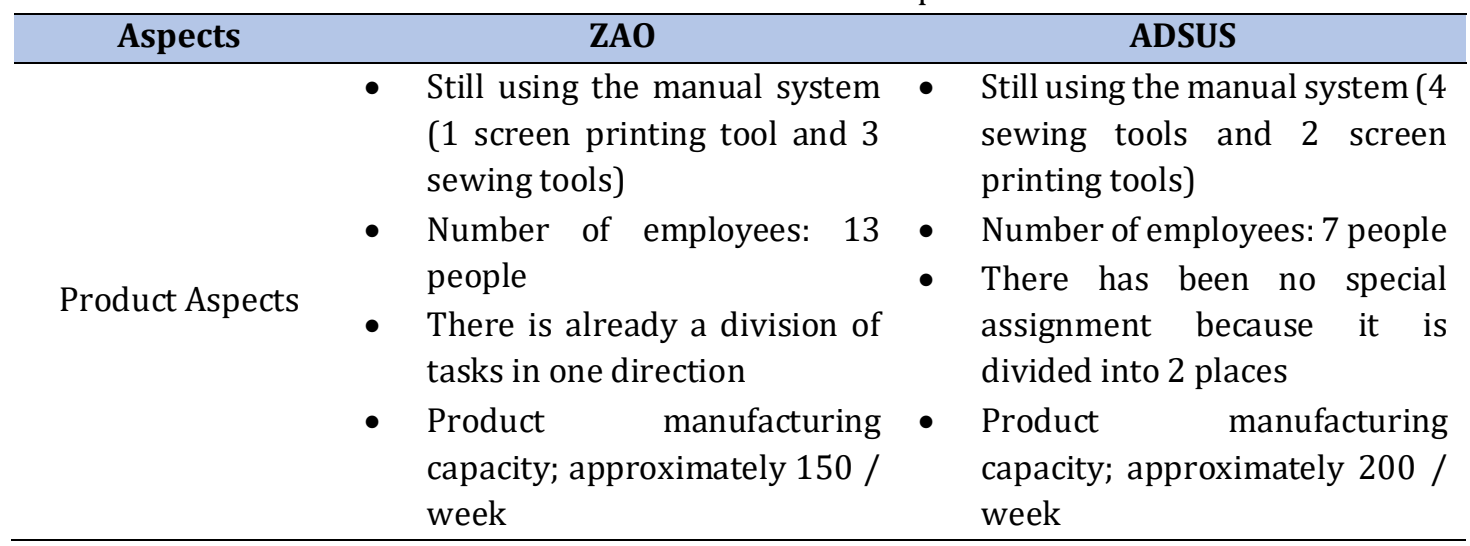

\section{Aspects of Human Resources}

The human resources employed in each company have almost the same background, namely the close relatives and families of the company owners. The human resources that are sought are those who are able to work and study, are not lazy and skilled at work and there are no formal requirements as in large companies. Human resources that are employed always receive compensation funds which are interpreted as work wages or salaries. The funds are provided with a "borong" system for ADSUS and a monthly salary for ZAO. 
With all the conditions mentioned above, it is known that the relationship between company owners and employees is going well and harmoniously. However, in these two companies there is no human resource training process before being contracted to work by the owner of the business entity. This is not in accordance with the theory which states that companies in obtaining human resources according to their needs must go through three stages, namely recruitment, training or lectures and job appraisals.

A company which has proactive and creative marketing employees can regularly launch even better and more interesting products and services. It can reach its customers in the right way, at the right place and time, by using interesting and memorable communication message, with the goal of outrivaling the competition and achieving as high market share as possible (Cvitanović, 2018). Human resource management (HRM), as a key player in the creation and development of a highly productive workforce, lies in the center of the debate on the competitiveness of businesses (Lepak et al., 2006; de Brito and de Oliveira, 2016). Practices that promote employee motivation and effort, knowledge, skills, and abilities, and opportunities for employee's contribution (Jiang et al., 2012; de Brito and de Oliveira, 2016) generate favorable conditions for the development of resources and capabilities that create value for organizations (BARNEY; WRIGHT, 1998), contributing to their performance and to the emergence of sustained competitive advantages (Huselid, 1995; Wright; Mcmahan; Mcwilliams, 1994; de Brito and de Oliveira, 2016).

\section{Management Aspects}

Companies that produce taekwondo equipment in Semarang City have basically implemented a management process. Judging from the four existing functions, the two companies have fulfilled these four functions. This is in line with the theory put forward by Sukirno (2006: 98-99) which states that from the planning function, all companies each have a company plan that has been set to support the progress and development of the company.

From the organizing function, both companies already have organizational structures. ADSUS and ZAO's organizers are still simple in nature, ZAO already has a good and more structured organization, including managers, treasurers, secretaries, in charge of production and in charge of shipping but have not been listed and written. Meanwhile, ADSUS is still dependent on the owner of the company.

The functions of direction, ADSUS and ZAO have divided work assignments to employees based on their respective fields and decisions by employees depend on the owner. The supervisory function, the evaluation process has been carried out by the two companies. Evaluation is carried out by the company owner and all employees, while the monthly evaluation is carried out by the company owner. ADSUS and ZAO also carry out supervision of the product before the product is marketed.

The two taekwondo equipment companies in Semarang City have fulfilled all the management elements. The management elements consist of: 1) Men, namely human labor, 2) Money, namely the money needed to achieve the goal, 3) Methods, namely the methods used in an effort to achieve goals, 4) Materials, namely the 
materials needed to reach the destination, 5) Machines, namely machines or tools that are needed or used to achieve the goal, 6) Market, which is a market for selling goods and services produced.

\section{Financial and Accounting Aspects}

The two taekwondo equipment companies in Semarang City have different financial circumstances. Where the finance for the initial capital of the company is obtained from the personal funds of the company founders who have different backgrounds and goals. Utilization of the existing initial capital in the company is used to procure materials and production machines. Procurement of production sites (factories), procurement of production materials and procurement of promotional funds. The existing capital and products are always developed and always innovated by the owners or authorized persons such as directors and partners, until the current company turnover is achieved.

Despite the intention for bringing closer very different standpoints and despite the aim to improved mutual understanding between marketing employees and accounting/finance employees, they will maintain different perceptions, way of working and approach to activities for which they share responsibility. Therefore, different conclusion can be made on the optimal way of organizing the implementation of such business tasks. In marketing function, proactivity and creativity are very important characteristics of each employee because through them Marketing managers ensure that key marketing function goals will be attained (Cvitanović, 2018).

\section{Information Systems Aspects}

All companies have owned and are able to take advantage of the information technology that is developing at this time. Examples of this information technology are websites, computers, e-mails, telephones, cell-phones. All of this information technology is used by the company in order to facilitate the company's work and support product marketing. However, in this case, ADSUS still does not make good use of technology compared to ZAO. Information and communication technologies (ICTs) are a significant enabler for enhancing decision-making and supporting knowledge creation within an organization. Companies that are not able to keep up with the pace of the latest ICT developments may lose their competitive advantage and the ability to compete under the same conditions as their competitors, leading to shrinking market share and profitability (Turban, et al. 2011; Compos, 2015).

Based on the results of the research and discussion obtained, it can be concluded, namely: The state of the taekwondo equipment industry business in the city of Semarang which is carried out in ZAO and ADSUS can be seen into 4 aspects:

a) Aspects of production: ZAO has 13 employees with 4 production tools so that he can maximize the production of products and ADSUS has 7 employees with 3 production tools that can fulfill consumer orders.

b) Product aspects: in terms of products made between ADSUS and ZAO having the same types of materials with different levels of comfort and innovation in product manufacturing. ADSUS and ZAO products are in demand by consumers so that many product orders from various regions are able to meet consumer order requests. 
c) Sales aspect: in terms of sales, both have implemented a plan according to consumer needs. When viewed from the monthly income ADSUS gets Rp. 30,000,000 and ZAO gets Rp. 25,000,000.

d) Marketing: ZAO and ADSUS are equally successful in marketing their products with their respective advantages. In his marketing, ZAO uses social media and relationships, while ADSUS uses relationships and participates in events.

The company has a fairly good management system because it fulfills the four management functions, namely planning, organizing, implementing and supervising.

\section{CONCLUSION}

Based on the results of existing research and discussion, the researchers suggest that taekwondo equipment companies in the city of Semarang maintain their existence in the business world of the Taekwondo Sports equipment industry, and continue to develop and improve all components of industrial business such as management, finance, human resources, operations, marketing and company information system so that later the company can create higher quality products and be able to compete with all similar companies in Indonesia and abroad. With the development of the taekwondo equipment industry business, it is hoped that it can contribute to the growth and development of the world of taekwondo sports in Indonesia and abroad and can improve the welfare of the Indonesian people.

\section{ACKNOWLEDGEMENT}

Our gratitude goes to ZAO and ADSUS companies for being the sample in this research

\section{REFERENCES}

Bloch, P. H., Black, W. C., \& Lichtenstein, D. (1989). Involvement with The Equipment Component of Sport: Links to Recreational Commitment. Leisure Sciences: An Interdisciplinary Journal, 11(3), 187-200. http://dx.doi.org/10.1080/01490408909512219.

Compos, J. (2015). Information Systems Development Aspects for The Mobile Web Technologies. Social Technologies, 5(1), 62-73.

Contreras, F. L., \& Ramos, M. L. Z. (2016). What is Marketing? A Study on Marketing Managers' Perception of the Definition of Marketing. Fórum Empresarial, 21(1), 4969.

Cvitanović, P. L. (2018). Managing Accounting and Financial Aspects of Marketing. Journal of Accounting and Management, 8(2), 83-94.

de Brito, R. P. \& de Oliveira, L. B. (2016). The Relationship Between Human Resource Management and Organizational Performance. Brazilian Business Review, 13(3), 90110. DOI: http://dx.doi.org/10.15728/bbr.2016.13.3.5

Ponto, J. (2015). Understanding and Evaluating Survey Research. Journal of the Advanced Practitioner in Oncology, 6(2), 168-171. 
Priyono, B. (2012). Pengembangan Pembangunan Industri Keolahragaan Berdasarkan Pendekatan Pengaturan Manajemen Pengelolaan Kegiatan Olahraga. Jurnal Media Ilmu Keolahragaan Indonesia, 2(2), 112-123. https://doi.org/10.15294/miki.v2i2.2651.

Putri, B. R. T. (2017). Manajemen Pemasaran. Denpasar

Schwab, K. A., Legg., E, Tanner, P., Timmerman, D., Dustin, D., \& Arthur-Banning, S. G. (2015). Career Paths in Sport Management. SCHOLE: A Journal of Leisure Studies and Recreation Education, 30:2, 1-11. https://doi.org/10.18666/schole-2015-v30-i26633

Ratten, V. (2016). Sport Innovation Management: Towards A Research Agenda. Innovation Management, Policy \& Practice, 18:3, 238-250. doi: 10.1080/14479338.2016.1244471

Raymond E. G, R.Steade, and J.R Lowry. 1996. Business: Its Nature and Environment. Cincinati: South Western

Robert, T. (2012). Understanding Survey Research: Applications and Processes. British Journal of Midwifery, 20(2), 114-120. Downloaded from magonlinelibrary.com by 052.064.078.187 on May 30, 2020.

Rusdi, M. (2019). Strategi Pemasaran untuk Meningkatkan Volume Penjualan pada Perusahaan Genting UD. Berkah Jaya. Jurnal Studi Manajemen dan Bisnis, 6(2), 49-54.

Undang-Undang Republik Indonesia Nomor 20 Tahun 2008 Tentang Usaha Mikro, Kecil Dan Menengah. 4 Juli 2008. Lembaran Negara Republik Indonesia Tahun 2008 Nomor 93. Jakarta

Undang-Undang Republik Indonesia Nomor 3 Tahun 2005 Tentang Sistem Keolahragaan Nasional. 23 September 2005. Lembaran Negara Republik Indonesia Tahun 2005 Nomor 89. Jakarta

Undang-Undang Republik Indonesia Nomor 3 Tahun 2005 Tentang Sistem Keolahragaan Nasional. 23 September 2005. Tambahan Lembaran Negara Republik Indonesia Nomor 4535. Jakarta

Wobowo, D. H., Arifin, Z., \& Sunarti. (2015). Analisis Strategi Pemasaran untuk Meningkatkan Daya Saing UMKM (Studi pada Batik Diajeng Solo). Jurnal Administrasi Bisnis, 29(1), 59-66.

Zhan, X. (2016). From Budding to Developing: The History of China's Sport Industry Policy. The International Journal of the History of Sport, 33(18), 2238-2252. http://dx.doi.org/10.1080/09523367.2017.1361409

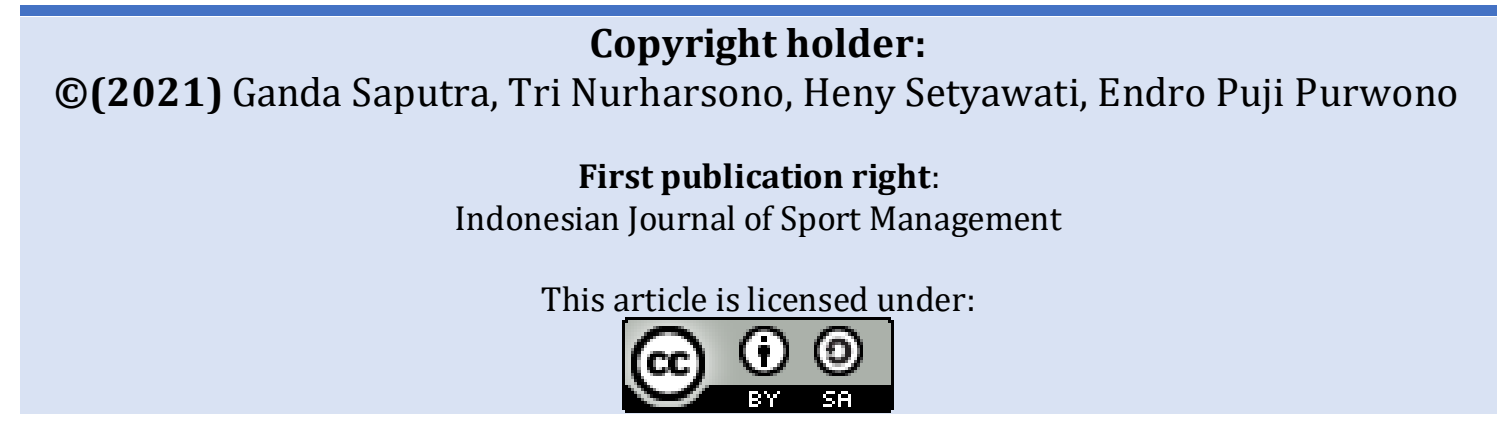

